J. Ris. \& Ap. Mat. Vol. 04 No. 02 (2020) pp. 115-136

Jurnal Riset dan Aplikasi Matematika

e-ISSN: 2581-0154

URL: journal.unesa.ac.id/index.php/jram

\title{
PEMILIHAN LOKASI PUSKESMAS BARU DI KABUPATEN SIDOARJO MENGGUNAKAN METODE FUZZY ANALYTICAL NETWORK PROCESS (FANP)
}

\author{
ATIEK SULISTYOWATI $^{1 *}$, Dwi JUNIATI ${ }^{2}$ \\ 1,2Jurusan Matematika, FMIPA, Universitas Negeri Surabaya \\ *atiksulistyowati7@gmail.com
}

\begin{abstract}
ABSTRAK
Puskesmas merupakan salah satu sarana atau fasilitas pelayanan kesehatan dasar yang banyak dimanfaatkan oleh masyarakat. Pada saat ini kebutuhan masyarakat akan pelayanan kesehatan semakin meningkat, salah satu penyebabnya adalah munculnya wabah virus COVID-19. Kabupaten Sidoarjo adalah satu satu daerah yang mempunyai kasus COVID-19 terbanyak di Jawa Timur. Alasan ini menjadi faktor pendorong pemerintah dan institusi penyelenggara pelayanan kesehatan untuk meningkatkan pemerataan dalam pelayanan kesehatan. Salah satu pelayanan kesehatan yang dibutuhkan adalah puskesmas dengan fasilitas rawat inap. Kenyataan di lapangan, puskesmas dengan layanan rawat inap belum merata di Sidoarjo. Oleh karena itu perlu dibangun puskesmas dengan fasilitas rawat inap di tempat yang strategis supaya efektif dan bermanfaat. Diperlukan adanya penelitian untuk pemilihan lokasi puskesmas baru yang strategis. Metode yang digunakan adalah Fuzzy Analytic Network Process (FANP) untuk menentukan alternatif lokasi terbaik. FANP merupakan gabungan dari metode fuzzy dan Analytic Network Process (ANP). Terdapat empat kriteria yang digunakan yaitu penduduk, Kondisi Geografis, Aksesibilitas, dan Jarak. Alternatif lokasi yang digunakan terdiri atas empat kecamatan, yaitu Kecamatan Buduran, Kecamatan Candi, Kecamatan Tanggulangin, dan Kecamatan Gedangan. Diperoleh hasil perhitungan dalam pemilihan lokasi puskesmas baru menunjukkan bahwa bobot lokasi di Kecamatan Buduran sebesar 0,296, bobot lokasi di Kecamatan Candi sebesar 0,651, bobot lokasi di Kecamatan Tanggulangin sebesar 0,480, dan bobot lokasi di Kecamatan Gedangan sebesar 0,334. Lokasi di Kecamatan Candi terpilih sebagai lokasi terbaik karena memiliki bobot tertinggi yang berada di Jl. Ngampelsari, Kedinding, Ngampelsari, Kec.Candi, Kab. Sidoarjo.
\end{abstract}

Kata Kunci: Puskesmas, Pemilihan lokasi, Fuzzy Analytic Network Process (FANP).

\begin{abstract}
The public health center is one of the facilities or health service facilities that are utilized by the community. At this time the community's need for health services is increasing, one of the causes is in the presence of a COVID-19 virus outbreak. Sidoarjo Regency is one of the regions that have the most cases of COVID-19 in East Java. this reason has become a motivating factor for the government and health providers to improve equity in health services. One of the health services needed is a public health center with inpatient facilities. The reality is found in the field, public health center with inpatient services have not been evenly distributed in Sidoarjo. Therefore, it is necessary to build a health center with inpatient
\end{abstract}

2010 Mathematics Subject Classification: 94D05

Tanggal Masuk: 19-10-20; direvisi: 22-10-20; diterima: 26-10-20 
facilities in strategic places to be effective and useful. Research is needed for the selection of new public health center locations. The method used was the Fuzzy Analytic Network Process (FANP) to determine the best alternative location. FANP is a combination of the fuzzy method and the Analytic Network Process (ANP). Four criteria were used for this research, these were Population, Geographical Conditions, Accessibility, and Distance. Alternative locations used to consist of four districts, namely Buduran District, Candi District, Tanggulangin District, and Gedangan District. Obtained from the results in the selection of new public health center locations, the location weight in Buduran District was 0. 296, the location weight in Candi District was 0.651, the location weight in Tanggulangin was 0.480, and the location weight in Gedangan was $\mathbf{0 . 3 3 4}$. Location in Candi Regency was chosen as the best location because it had the highest weight which is on Jl. Ngampelsari, Kedinding, Ngampelsari, Kec.Candi, Kab. Sidoarjo.

Keywords: Public health center, Location Selection, Fuzzy Analytic Network Process (FANP).

\section{Pendahuluan}

Pusat kesehatan masyarakat (puskesmas) merupakan fasilitas pelayanan kesehatan yang menyelenggarakan Upaya Kesehatan Masyarakat (UKM) dan Upaya Kesehatan Perseorangan (UKP) tingkat pertama, dengan lebih mengutamakan upaya promotif dan preventif untuk mencapai derajat kesehatan masyarakat yang setinggi-tingginya di wilayah kerjanya [1]. Puskesmas merupakan salah satu sarana atau fasilitas pelayanan kesehatan dasar yang banyak dimanfaatkan oleh masyarakat. Tugas puskesmas adalah melaksanakan kebijakan kesehatan untuk mencapai tujuan pembangunan kesehatan di wilayah kerjanya dalam rangka mendukung terwujudnya kecamatan sehat [2]. Pengelolaan dan pembinaan puskesmas diserahkan kepada pemerintah daerah Kabupaten/Kota. Di Indonesia puskesmas harus didirikan pada setiap kecamatan, tetapi dalam kondisi tertentu pada satu kecamatan dapat didirikan lebih dari satu puskesmas. Kondisi yang dimaksud berdasarkan pertimbangan kebutuhan pelayanan, jumlah penduduk dan aksesibilitas.

Pada saat ini kebutuhan masyarakat akan pelayanan kesehatan semakin meningkat, salah satu penyebabnya adalah munculnya wabah virus yang berasal dari kota Wuhan yaitu Coronaviruses (CoV) atau yang lebih dikenal dengan nama COVID-19. Dimana COVID-19 termasuk dalam keluarga besar virus yang menyebabkan penyakit mulai dari flu biasa hingga penyakit lebih parah seperti Middle East Respiratory Syndrome (MERS). Kabupaten Sidoarjo adalah satu satu daerah yang mempunyai kasus COVID-19 terbanyak di Jawa Timur. Alasan ini menjadi faktor pendorong pemerintah dan institusi penyelenggara pelayanan kesehatan untuk meningkatkan pemerataan dalam pelayanan kesehatan. Salah satu pelayanan kesehatan yang dibutuhkan adalah puskesmas dengan fasilitas rawat inap. Jumlah puskesmas di Kabupaten Sidoarjo pada tahun 2018 adalah 26 puskesmas dengan status terakreditasi yang terbagi dalam 18 kecamatan. Dari 26 puskesmas, 15 puskesmas adalah puskesmas dengan rawat inap dan 11 puskesmas rawat jalan [3].

Kabupaten Sidoarjo terdapat 18 wilayah kecamatan yang terbagi menjadi 322 desa dan 31 kelurahan [4]. Dimana ada beberapa kecamatan yang belum mempunyai puskesmas dengan fasilitas rawat inap sedangkan fasilitas tersebut sangat diperlukan saat ini. salah satu contoh 
adalah kecamatan Tanggulangin. Kenyataan di lapangan, puskesmas dengan layanan rawat inap belum merata di Sidoarjo. Oleh karena itu perlu dibangun puskesmas dengan fasilitas rawat inap di tempat yang strategis supaya efektif dan bermanfaat. Sehingga perlu adanya analisis dan rekomendasi pemilihan lokasi puskesmas baru di wilayah Kabupaten Sidoarjo sehingga dapat meningkatkan pemerataan dalam pelayanan kesehatan. Dalam pemilihan lokasi puskesmas baru diperlukan suatu metode tentang pengambilan keputusan yang dapat digunakan untuk menentukan prioritas sehingga dapat mengurangi unsur subjektivitas para ahli.

Multiple Criteria Decision Making (MCDM) merupakan suatu metode pengambilan keputusan untuk menetapkan alternatif terbaik dari sejumlah alternatif berdasarkan beberapa kriteria tertentu [5]. Salah satu metode pembobotan yang biasa digunakan dalam MCDM adalah Analytical Network Process (ANP). Metode ini pertama kali dipublikasikan oleh Thomas L. Saaty. Metode Analytical Network Process (ANP) adalah generalisasi dari metode Analytical Hirarchy Process (AHP) memberikan sebuah bentuk kerangka kerja untuk masalah pengambilan keputusan dengan asumsi ketergantungan antar kriteria dan altenatif [6]. Fuzzy Analytical Network Process (FANP) adalah gabungan dari metode fuzzy dan Analytical Network Process (ANP). Metode fuzzy digunakan untuk mengubah penilaian subjektif para ahli ke skala rasio Triangular Fuzzy Number (TFN) kemudian diolah menggunakan Analytical Network Process (ANP) [7]. Diperoleh hasil pemeringkatan dalam pemilihan lokasi puskesmas baru.

Kriteria dan subkriteria yang digunakan dalam penelitian ini didapat berdasarkan Peraturan Menteri Kesehatan Republik Indonesia Nomor 75 Tahun 2014 tentang Pusat Kesehatan Masyarakat dan referensi dari jurnal lainnya. Terdapat 4 kriteria yang digunakan adalah penduduk, kondisi geografis, aksesibiltas, dan jarak. Dan 9 subkriteria yang digunakan adalah jumlah penduduk, kepadatan penduduk, luas tanah, kontur tanah, ketersediaan tempat parkir, fasilitas keamanan, ketersediaan utilitas publik, jarak antar puskesmas, dan jarak puskesmas dari permukiman. Pada penelitian sebelumnya, metode FANP mampu menyelesaikan masalah pemilihan lokasi seperti yang dilakukan oleh Shahbandarzadeh dan Ghorbanpour yang menggunakan FANP dalam menentukan pemilihan lokasi pusat kesehatan yang akan datang di wilayah Ramsar, Iran [8] serta Oktavia dan Usadha yang menggunakan FANP untuk menentukan prioritas pemeliharaan jalan [9]. Dari penelitian ini, diharapkan dapat membantu pihak pemerintah Kabupaten Sidoarjo dalam menentukan pemilihan lokasi puskesmas baru di Kabupaten Sidoarjo yang sesuai dan tepat sasaran.

\section{Tinjauan Pustaka}

\subsection{Himpunan Fuzzy}

Teori himpunan fuzzy diperkenalkan oleh Lotfi A. Zadeh pada tahun 1965. Zadeh memperkenalkan teori himpunan fuzzy untuk menangani ketidakpastian karena ketidaktepatan dan ketidakjelasan. Kontribusi utama teori himpunan fuzzy adalah kemampuannya merepresentasikan data yang tidak jelas. Pada dasarnya, teori himpunan fuzzy merupakan perluasan dari teori himpunan klasik (crisp)[5]. Suatu nilai yang menunjukkan seberapa besar tingkat keanggotaan suatu elemen $(x)$ dalam suatu himpunan $(A)$, dinotasikan dengan $\mu_{A}(x)$. 
Pada himpunan klasik, hanya ada 2 nilai keanggotaan, yaitu $\mu_{A}(x)=1$ untuk $x$ menjadi anggota, dan $\mu_{A}(x)=0$ untuk $x$ bukan menjadi anggota $A$ [5]. Setiap himpunan fuzzy dapat dinyatakan dengan suatu fungsi keanggotaan (membership function), yaitu suatu kurva yang menunjukkan pemetaan titik-titik input data ke dalam nilai keanggotaannya (derajat keanggotaan) yang memiliki interval antara 0 sampai 1. Nilai keanggotaan dapat diperoleh melalui beberapa pendekatan fungsi, antara lain representasi linier, trapesium (trapeziodal), dan segitiga (triangular) [10].

\subsection{Triangular Fuzzy Number (TFN)}

Triangular Fuzzy Number mempunyai tiga parameter, yaitu $(l, m, u)$ dengan $l \leq m \leq u$, yang dinyatakan dengan segitiga $(x ; l, m, u)$. Parameter $l, m, u$ masing-masing menunjukkan batas bawah (lower), nilai tengah (medium), batas atas (upper) dari TFN, dengan fungsi keanggotaan sebagai berikut [11]:

$$
\mu(x)=\left\{\begin{array}{l}
0 ; x \leq l \text { atau } x \geq u \\
\frac{(x-l)}{(m-l)} ; l \leq x \leq m \\
\frac{(m-x)}{(u-m)} ; m \leq x \leq u
\end{array}\right.
$$

Fungsi keanggotaan dalam Triangular Fuzzy Number (TFN) disajikan pada Gambar 1:

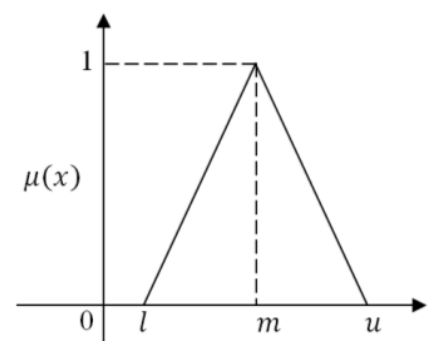

Gambar 1 : Fungsi Keanggotaan Triangular Fuzzy Number (TFN)

\subsection{Analytical Network Process (ANP)}

Metode Analytical Network Process (ANP) merupakan pengembangan dari metode Analytical Hierarchy Process (AHP). Model metode ini berbentuk jaringan sehingga dapat diketahui saling keterkaitan antara subkriteria yang ada pada satu kriteria yang sama, ataupun terhadap subkriteria - subkriteria pada kriteria yang berbeda. Metode Analytical Network Process (ANP) terdapat dua jenis keterkaitan, yaitu hubungan/keterkaitan antar subkriteria dalam sebuah kriteria (inner dependence) dan menunjukkan hubungan/keterkaitan antara masing masing kriteria (outer dependence). Saling keterkaitan kriteria satu dengan kriteria lainnya disebut feedback [12].

Adanya keterkaitan tersebut menyebabkan metode Analytical Network Process (ANP) lebih kompleks dibanding metode Analytical Hierarchy Process (AHP). Karena keterkaitan itu pula menyebabkan metode Analytical Network Process (ANP) mampu memperbaiki kelemahan metode Analytical Hierarchy Process (AHP) berupa kemampuan mengakomodasi keterkaitan antar kriteria atau alternatif [13]. Kriteria dalam metode Analytical Network Process (ANP) 
disebut cluster dan subkriteria disebut node. ANP digunakan dalam struktur jaringan dengan loop umpan balik (jaringan umpan balik) seperti yang ditunjukkan pada Gambar 2 [14].

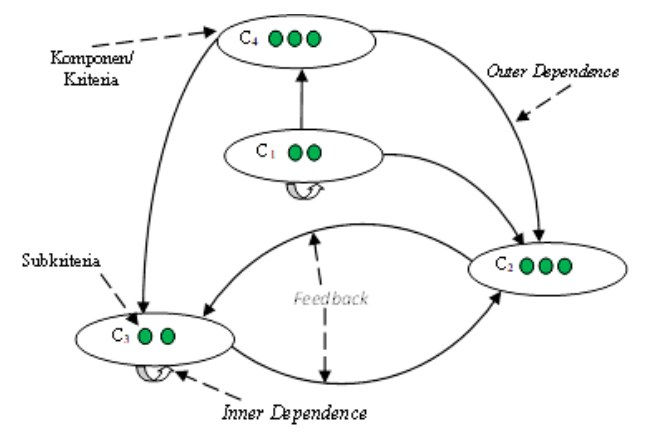

Gambar 2 : Struktur Metode Analytical Network Process (ANP) Berbentuk Jaringan Feedback

\subsection{Fuzzy Analytical Network Process (FANP)}

Metode Fuzzy Analytical Network Process (FANP) merupakan gabungan metode fuzzy dan metode Analytical Network Process (ANP). Metode Analytical Network Process (ANP) dapat menentukan kriteria yang paling penting dan mempunyai pengaruh yang sangat besar [15]. Pendekatan fuzzy, dalam hal ini Triangular Fuzzy Number (TFN) digunakan untuk mengatasi adanya informasi dan data yang tidak lengkap serta mengakomodasi sifat samar pengambil keputusan dalam memberikan penilaian sehingga dapat mengatasi ketidakpastian di dalam kriteria-kriteria kualitatif [9].

Langkah-langkah metode Fuzzy Analytical Network Process (FANP) sebagai berikut:

1. Penyusunan struktur hierarki

2. Pengumpulan data berdasarkan tingkat kepentingan relatif melalui kuesioner.

Data yang digunakan adalah data penilaian dari semua pengambil keputusan (responden) terhadap tingkat kepentingan relatif setiap kriteria dan subkriteria secara berpasangan. Data yang bersifat linguistik diubah menjadi skala numerik 1-9. Nilai dan definisi pendapat kualitatif skala perbandingan Saaty dapat dilihat pada Tabel 1:

Tabel 1 : Skala Perbandingan Berpasangan

\begin{tabular}{|c|l|}
\hline Skala Numerik & \multicolumn{1}{c|}{ Skala Linguistik } \\
\hline 1 & Kedua kriteria sama penting \\
\hline 3 & Kriteria $i$ sedikit lebih penting dibanding dengan kriteria $j$ \\
\hline 5 & Kriteria $i$ lebih penting dibanding dengan kriteria $j$ \\
\hline 7 & Kriteria $i$ sangat lebih penting dibanding dengan kriteria $j$ \\
\hline 9 & Kriteria $i$ mutlak lebih penting dibanding dengan kriteria $j$ \\
\hline $2,4,6,8$ & $\begin{array}{l}\text { Jika ragu-ragu antara 2 skala maka ambil nilai tengahnya, } \\
\text { yaitu 2, 4, 6, atau 8 }\end{array}$ \\
\hline
\end{tabular}

3. Penyusunan perbandingan matriks berpasangan antar kriteria pada tiap data responden. 
Misalkan matriks $A$ adalah perbandingan berpasangan dari kriteria yang diketahui, matriks $A$ dibuat dengan meletakkan hasil dari perbandingan berpasangan elemen $i$ dengan elemen $j$ kedalam posisi $a_{i j}$ sebagai berikut [16]:

$$
A=\begin{gathered}
C_{1} \\
C_{2} \\
C_{2} \\
\vdots \\
C_{n}
\end{gathered}\left[\begin{array}{cccc}
1 & a_{12} & \ldots & C_{n} \\
a_{21} & 1 & \ldots & a_{2 n} \\
\vdots & \vdots & 1 & \vdots \\
a_{n 1} & a_{n 2} & \ldots & 1
\end{array}\right]
$$

dengan:

$n=$ jumlah kriteria yang akan dibandingkan

$C_{i}=$ kriteria ke- $i$, dimana $i=1,2, \ldots, n$

$a_{i j}=$ tingkat kepentingan kriteria ke- $i$ terhadap kriteria ke- $j$.

4. Menghitung matriks normalisasi.

Matriks normalisasi digunakan untuk mencari nilai eigen yang digunakan untuk proses uji konsistensi. Misalkan matriks $A N$ adalah matriks normalisasi kolom, yaitu matriks yang entrinya diperoleh dari normalisasi nilai setiap kolom matriks $A$ dengan membagi setiap nilai pada kolom matriks dengan hasil penjumlahan kolom yang bersesuaian dan matriks $A R$ merupakan matriks yang diperoleh dari rata-rata penjumlahan setiap baris matriks normalisasi $A N$.

$$
\begin{aligned}
& A N=\begin{array}{c}
C_{1} \\
C_{2} \\
\vdots \\
C_{3}
\end{array}\left[\begin{array}{ccccc}
\frac{1}{a_{11}+a_{21}+\cdots+a_{n 1}} & \frac{a_{12}}{a_{12}+a_{22}+\cdots+a_{n 2}} & \cdots & \frac{a_{1 n}}{a_{1 n}+a_{2 n}+\cdots+a_{n n}} \\
\frac{a_{21}}{a_{11}+a_{21}+\cdots+a_{n 1} 1} & \frac{1}{a_{12}+a_{22}+\cdots+a_{n 2}} & \cdots & \frac{a_{2 n}}{a_{1 n}+a_{2 n}+\cdots+a_{n n}} \\
\frac{a_{n 1}}{a_{11}+a_{21}+\cdots+a_{n 1}} & \frac{a_{n 2}}{a_{12}+a_{22}+\cdots+a_{n 2}} & \cdots & \frac{a_{n n}}{a_{1 n}+a_{2 n}+\cdots+a_{n n}}
\end{array}\right]
\end{aligned}
$$

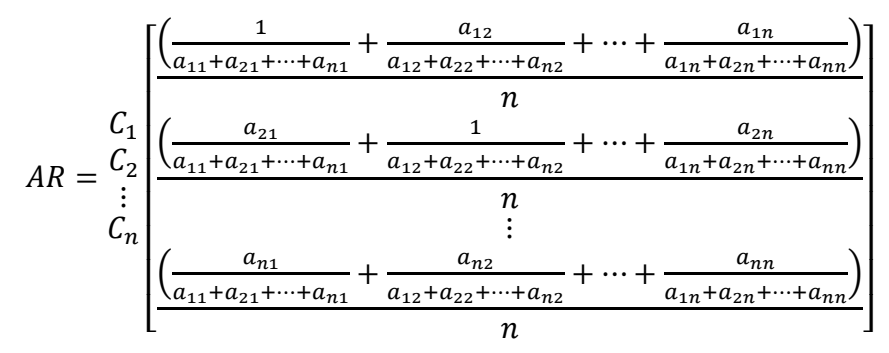

5. Mencari nilai eigen maksimum matriks berpasangan $\left(\lambda_{\max }\right)$

Perhitungan $\lambda_{\text {max }}$ dilakukan dengan membentuk matriks $C$ dimana elemennya merupakan hasil kali matriks $A$ dengan matriks $A R$. Rumus untuk mencari $\lambda_{\max }[9]$ :

$$
\lambda_{\max }=\frac{\sum_{i=1}^{n} \frac{c_{i 1}}{a r_{i 1}}}{n}
$$

dengan:

$\lambda_{\max }=$ nilai eigen maksimum

$n$ = banyaknya elemen yang dibandingkan / jumlah kriteria

$c_{i 1}=$ elemen ke- $i$ dari matriks $\mathrm{C}$ 
$a r_{i 1}=$ elemen ke- $i$ dari matriks $A R$

6. Uji konsistensi pada data perbandingan berpasangan

Tujuan uji konsistensi pada perbandingan berpasangan adalah untuk memperoleh keputusan yang rasional sehingga data yang telah dinyatakan konsisten dapat digunakan untuk menentukan bobot prioritas. Rumus menghitung Consistency Index (CI):

$$
C I=\frac{\lambda_{\max }-n}{n-1}
$$

dengan:

CI = Indeks Konsistensi (Consistency Index)

$\lambda_{\text {max }}=$ nilai eigen maksimum

$n$ = banyaknya elemen yang dibandingkan / jumlah kriteria

Setelah diperoleh nilai Consistency Index (CI), selanjutnya menentukan Consistency Ratio $(C R)$ kemudian dijumlahkan. Matriks perbandingan berpasangan dinyatakan konsisten apabila rasio konsistensi $(C R) \leq 0,1$ [17]. Rumus untuk menghitung Consistency Ratio $(C R)$ :

$$
C R=\frac{C I}{I R}
$$

dengan:

$C R \quad=$ Rasio Konsistensi (Consistency Ratio)

$C I \quad=$ Indeks Konsistensi (Consistency Index)

$I R \quad=$ Random Indeks (Index Random)

Nilai Indeks Random (IR) dapat dilihat melalui Tabel 2 [18] :

Tabel 2: Nilai Index Random (IR)

\begin{tabular}{|c|c|}
\hline $\boldsymbol{n}$ & $\boldsymbol{I R}$ \\
\hline 1 & 0,00 \\
\hline 2 & 0,00 \\
\hline 3 & 0,52 \\
\hline 4 & 0,89 \\
\hline 5 & 1,11 \\
\hline 6 & 1,25 \\
\hline 7 & 1,35 \\
\hline 8 & 1,40 \\
\hline 9 & 1,45 \\
\hline 10 & 1,49 \\
\hline 11 & 1,51 \\
\hline 12 & 1,54 \\
\hline 13 & 1,56 \\
\hline 14 & 1,57 \\
\hline 15 & 1,58 \\
\hline
\end{tabular}


7. Mengubah bobot penilaian perbandingan berpasangan yang telah konsisten ke dalam Triangular Fuzzy Number (TFN)

Ketentuan perubahan dari skala numerik kedalam bentuk Triangular Fuzzy Number (TFN) dapat dilihat pada Tabel 3[19] :

Tabel 3: Ketentuan Fungsi Keanggotaan Skala Triangular Fuzzy Number

\begin{tabular}{|c|c|}
\hline Skala Numerik & Fungsi Keanggotaan $(\boldsymbol{l}, \boldsymbol{m}, \boldsymbol{u})$ \\
\hline$x$ & $\left(\frac{x+1}{4}, \frac{x+3}{4}, \frac{x+5}{4}\right)$ \\
\hline
\end{tabular}

8. Menghitung rata-rata geometrik.

Rata-rata geometrik adalah akar pangkat $n$ hasil perkalian data. Jika seperangkat data adalah $x_{1}, x_{2}, \ldots, x_{n}$ maka rata-rata geometriknya dapat dihitung menggunakan persamaan berikut [20]:

$$
\bar{y}_{g}=\sqrt[n]{\prod_{i=1}^{n} x_{i}}=\left(\prod_{i=1}^{n} x_{i}\right)^{\frac{1}{n}}
$$

dengan:

$\bar{y}_{g}=$ rata-rata geometrik

$x_{i}=$ data ke $i$

$n$ = banyak data

9. Menghitung nilai sintesis fuzzy

Dari rata-rata geometrik yang diperoleh kemudian dihitung nilai sintesis fuzzy menggunakan persamaan berikut [21]:

$$
S_{i}=\sum_{j=1}^{m} M_{g i}^{j} \otimes\left[\sum_{i=1}^{n} \sum_{j=1}^{m} M_{g i}^{j}\right]^{-1}
$$

dimana,

$$
\begin{gathered}
\sum_{j=1}^{m} M_{g i}^{j}=\left(\sum_{j=1}^{m} l_{i}, \sum_{j=1}^{m} m_{i}, \sum_{j=1}^{m} u_{i}\right) \\
{\left[\sum_{i=1}^{n} \sum_{j=1}^{m} M_{g i}^{j}\right]^{-1}=\left(\frac{1}{\sum_{j=1}^{m} u_{i}, \sum_{j=1}^{m} m_{i}, \sum_{j=1}^{m} l_{i}}\right)}
\end{gathered}
$$

dengan:

$S_{i}=$ nilai sintesis fuzzy

$M_{g i}^{j}=$ nilai triangular fuzzy number untuk $i=1,2, \ldots, j$

$l=$ batas bawah (lower)

$m=$ nilai tengah (median)

$u=$ batas atas (upper) 
10. Menghitung derajat kemungkinan dari $M_{i} \geq M_{j}$

Misalkan $M_{i}$ adalah nilai sintesis fuzzy kriteria ke- $i$ dengan $i=1,2,3, \ldots, n$ dan $M_{j}$ adalah nilai sintesis fuzzy kriteria ke- $j$ dengan $j=1,2,3, \ldots, n$ Rumus derajat kemungkinan dari $M_{i}\left(l_{i}, m_{i}, u_{i}\right) \geq M_{j}\left(l_{j}, m_{j}, u_{j}\right) M_{i} \quad[21]:$

$$
\left(M_{i} \geq M_{j}\right)=\mu_{K a}(d)\left\{\begin{array}{c}
1, j \text { ika } m_{i} \geq m_{j} \\
0, \text { jika } l_{j} \geq u_{i} \\
\frac{l_{j}-u_{i}}{\left(m_{i}-u_{i}\right)-\left(m_{j}-l_{j}\right)}, \text { untuk nilai yang lain }
\end{array}\right.
$$

11. Melakukan perbandingan nilai Fuzzy Synthetic Extent dan nilai minimumnya

Perbandingan nilai fuzzy synthetic extent dan nilai minimumnya didefinisikan sebagai berikut [21]:

$$
\begin{gathered}
V\left(M_{i} \geq M_{1}, M_{2}, \ldots, M_{k}\right)=V\left[\left(M_{i} \geq M_{1}\right) \wedge\left(M_{i} \geq M_{2}\right) \wedge \ldots \wedge\left(M_{i} \geq M_{k}\right)\right] \\
=\min V\left(M_{i} \geq M_{k}\right), \text { dengan } k=1,2, \ldots, n ; k \neq i
\end{gathered}
$$

12. Perhitungan vektor bobot dan normalisasi vektor bobot

Perhitungan tersebut dilakukan untuk mendapatkan bobot nilai setiap level kriteria. Asumsikan bahwa:

$$
d^{\prime}\left(A_{i}\right)=\min V\left(M_{i} \geq M_{k}\right)
$$

Untuk $k=1,2, \ldots, n ; k \neq i$

Maka bobot vektor didefinisikan sebagai berikut:

$$
W^{\prime}=\left(d^{\prime}\left(A_{1}\right), d^{\prime}\left(A_{2}\right), \ldots, d^{\prime}\left(A_{n}\right)\right)^{T}
$$

dimana $A_{1}(i=1,2,3, \ldots, n)$ adalah $n$ kriteria/ elemen keputusan. Kemudian vektor bobot tersebut di normalisasi menjadi [21]:

$$
W=\left(d^{\prime}\left(A_{1}\right), d^{\prime}\left(A_{2}\right), \ldots, d^{\prime}\left(A_{n}\right)\right)^{T}
$$

13. Diperoleh hasil bobot kriteria.

\section{Metode Peneletian}

\subsection{Studi Pendahulan}

Pada tahap ini dilakukan observasi permasalahan, identifikasi permasalahan, studi literatur mengenai pemilihan lokasi puskesmas baru dan metode Fuzzy Analytical Network Process (FANP). 


\subsection{Pengumpulan Data}

Data yang digunakan dalam penelitian ini adalah data primer berupa hasil pengisian kuesioner para ahli berupa perbandingan berpasangan antar kriteria dan subkriteria untuk pemilihan lokasi puskesmas baru. Selanjutnya, data sekunder yang digunakan dalam penelitian ini adalah data yang diperoleh dari BPS Kabupaten Sidoarjo berupa data jumlah penduduk menurut kecamatan di Kabupaten Sidoarjo dan kepadatan penduduk di Kabupaten Sidoarjo. Data mengenai puskesmas di Kabupaten sidoarjo diperoleh dari profil kesehatan Kabupaten Sidoarjo tahun 2018. Data jarak lokasi alternatif dengan puskesmas terdekat, data jarak lokasi alternatif dari permukiman terdekat, dan data jarak lokasi dengan polsek diperoleh dengan bantuan Google maps. Luas tanah dan kontur tanah diperoleh dengan aplikasi Google Earth Pro.

\subsection{Pengolahan Data dengan Metode FANP}

Data yang telah diperoleh berupa matriks perbandingan berpasangan dengan nilai Triangular Fuzzy Number (TFN) kemudian diolah menggunakan metode Fuzzy Analytical Network Process (FANP) untuk menentukan bobot masing-masing kriteria dan subkriteria.

\subsection{Analisis Hasil dan Kesimpulan}

Pada tahap ini membahas hasil yang diperoleh dari pengolahan metode FANP dan kesimpulannya.

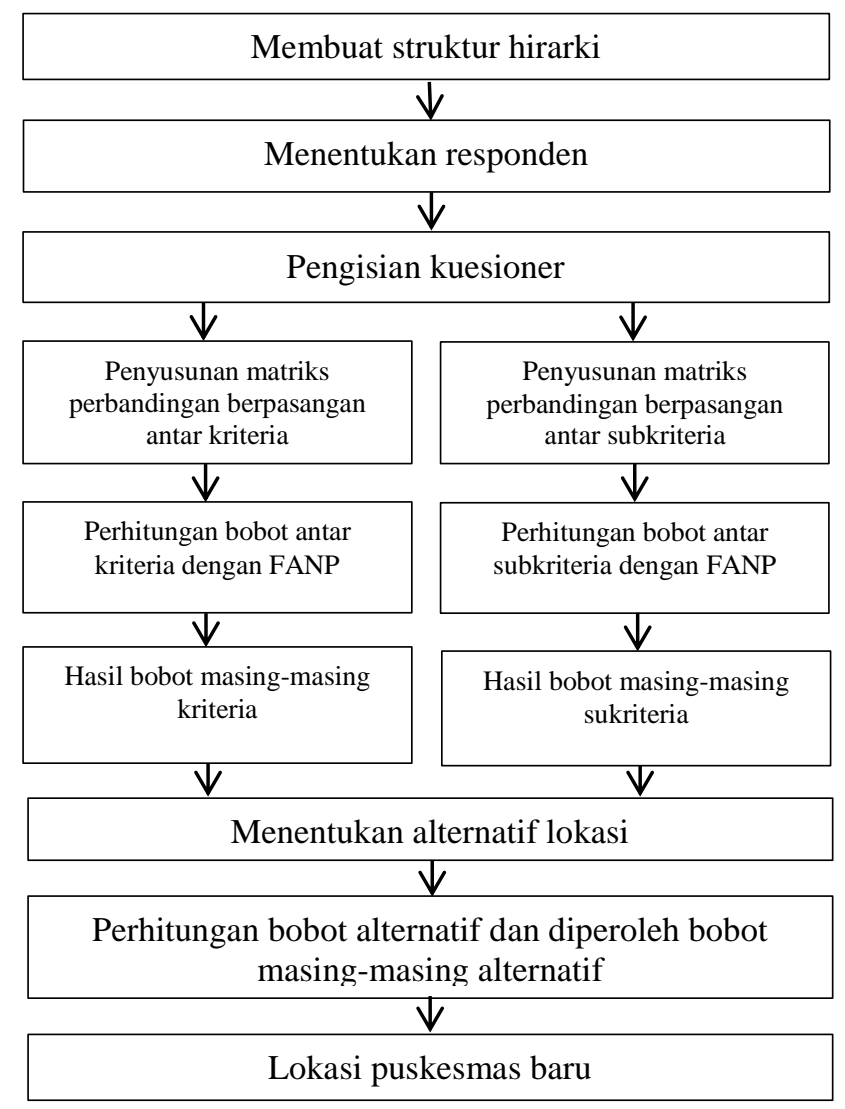

Gambar 3 : Diagram Alur Rancangan Penelitian 


\section{Hasil dan Pembahasan}

\subsection{Pembagian kuesioner}

Kuesioner di bagikan kepada responden dalam bentuk perbandingan berpasangan yang berupa perbandingan tingkat kepentingan antar kriteria dan antar subkriteria. Responden dalam penelitian ini adalah orang-orang yang bekerja di bidang kesehatan yaitu dokter rumah sakit, perawat, bidan, dan pegawai pemerintah provinsi di bagian analisis pemberi bantuan dana untuk pembangunan daerah.

\subsection{Penentuan kriteria dan subkriteria}

Kriteria dan subkriteria yang digunakan dalam penelitian ini berdasarkan Peraturan Menteri Kesehatan Republik Indonesia Nomor 75 Tahun 2014 tentang Pusat Kesehatan Masyarakat (puskesmas) dan referensi jurnal lain.

Tabel 4: Kriteria dan Subkriteria Pemilihan Lokasi Puskesmas Baru

\begin{tabular}{|c|c|c|}
\hline No & Kriteria & Subkriteria \\
\hline \multirow{2}{*}{1} & \multirow{2}{*}{ Penduduk (K1) } & Jumlah Penduduk (S1) \\
\hline & & Kepadatan Penduduk (S2) \\
\hline \multirow{2}{*}{2} & \multirow{2}{*}{$\begin{array}{l}\text { Kondisi Geografis } \\
\text { (K2) }\end{array}$} & Luas Tanah (S3) \\
\hline & & Kontur Tanah (S4) \\
\hline \multirow{3}{*}{3} & \multirow{3}{*}{ Aksesibilitas (K3) } & Ketersediaan Tempat Parkir (S5) \\
\hline & & Fasilitas Keamanan (S6) \\
\hline & & Ketersediaan Utilitas Publik (S7) \\
\hline \multirow{2}{*}{4} & \multirow{2}{*}{ Jarak (K4) } & Jarak Antar Puskesmas (S8) \\
\hline & & Jarak Puskesmas dari Permukiman (S9) \\
\hline
\end{tabular}

\subsection{Penentuan bobot kriteria dan subkriteria}

Pada tahap ini bertujuan untuk mengetahui bobot masing-masing kriteria dan subkriteria yang di peroleh dari penyebaran kuesioner perbandingan tingkat kepentingan antar kriteria dan antar subkriteria kepada para ahli kemudian dimasukkan ke dalam matriks perbandingan berpasangan. Berikut matriks rata-rata perbandingan berpasangan kriteria dan subkriteria.

Tabel 5 : Matriks Rata-Rata Perbandingan Berpasangan Kriteria

\begin{tabular}{|c|c|c|c|c|}
\hline $\begin{array}{ll}\text { Kriteria } i & \text { Kriteria } j \\
\end{array}$ & K1 & K2 & K3 & K4 \\
\hline Penduduk (K1) & 1,000 & 3,800 & 0,319 & 3,040 \\
\hline Kondisi Geografis (K2) & $\frac{1}{3,800}=0,263$ & 1,000 & 0,350 & 1,307 \\
\hline Aksesibilitas (K3) & $\frac{1}{0,319}=3,135$ & $\frac{1}{0,350}=2,857$ & 1,000 & 2,840 \\
\hline Jarak (K4) & $\frac{1}{3,040}=0,329$ & $\frac{1}{1,307}=0,765$ & $\frac{1}{2,840}=0,352$ & 1,000 \\
\hline 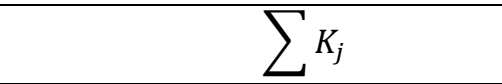 & 4,727 & 8,422 & 2,021 & 8,187 \\
\hline
\end{tabular}


Tabel 6 : Matriks Rata-Rata Perbandingan Berpasangan Subkriteria

\begin{tabular}{|c|c|c|c|c|c|c|c|c|c|}
\hline $\begin{array}{r}\text { Subkriteria } j \\
\text { Subkriteria } i\end{array}$ & S1 & S2 & S3 & S4 & S5 & S6 & S7 & S8 & S9 \\
\hline Jumlah Penduduk (S1) & 1,000 & 1,057 & 2,650 & 3,800 & 3,800 & 3,800 & 2,240 & 3,040 & 1,690 \\
\hline $\begin{array}{l}\text { Kepadatan Penduduk } \\
\text { (S2) }\end{array}$ & $\begin{array}{l}\frac{1}{1,057} \\
=0,946\end{array}$ & 1,000 & 3,600 & 3,600 & 4,200 & 4,200 & 2,840 & 2,840 & 3,240 \\
\hline Luas Tanah (S3) & $\begin{array}{l}\frac{1}{2,650} \\
=0,377\end{array}$ & $\begin{array}{l}\frac{1}{3,600} \\
=0,278\end{array}$ & 1,000 & 2,400 & 3,600 & 3,600 & 2,440 & 1,840 & 1,640 \\
\hline Kontur Tanah (S4) & $\begin{array}{l}\frac{1}{3,800} \\
=0,263\end{array}$ & $\begin{array}{l}\frac{1}{3,600} \\
=0,278\end{array}$ & $\begin{array}{l}\frac{1}{2,400} \\
=0,417\end{array}$ & 1,000 & 3,200 & 3,000 & 0,323 & 0,323 & 0,857 \\
\hline $\begin{array}{l}\text { Ketersediaan Tempat } \\
\text { Parkir (S5) }\end{array}$ & $\begin{array}{l}\frac{1}{3,800} \\
=0,263\end{array}$ & $\begin{array}{l}\frac{1}{4,200} \\
=0,238\end{array}$ & $\begin{array}{l}\frac{1}{3,600} \\
=0,278\end{array}$ & $\begin{array}{l}\frac{1}{3,200} \\
=0,313\end{array}$ & 1,000 & 0,313 & 0,347 & 0,253 & 0,253 \\
\hline Fasilitas Keamanan (S6) & $\begin{aligned} & \frac{1}{3,800} \\
= & 0,263\end{aligned}$ & $\begin{aligned} & \frac{1}{4,200} \\
= & 0,238\end{aligned}$ & $\begin{aligned} & \frac{1}{3,600} \\
= & 0,278\end{aligned}$ & $\begin{aligned} & \frac{1}{3,000} \\
= & 0,333\end{aligned}$ & $\begin{aligned} & \frac{1}{0,313} \\
= & 3,195\end{aligned}$ & 1,000 & 0,823 & 0,263 & 1,013 \\
\hline $\begin{array}{l}\text { Ketersediaan Utilitas } \\
\text { Publik (S7) }\end{array}$ & $\begin{aligned} & \frac{1}{2,240} \\
= & 0,446\end{aligned}$ & $\begin{aligned} & \frac{1}{2,840} \\
= & 0,352\end{aligned}$ & $\begin{aligned} & \frac{1}{2,440} \\
= & 0,410\end{aligned}$ & $\begin{aligned} & \frac{1}{0,323} \\
= & 3,096\end{aligned}$ & $\begin{aligned} & \frac{1}{0,347} \\
= & 2,882\end{aligned}$ & $\begin{aligned} & \frac{1}{0,823} \\
= & 1,215\end{aligned}$ & 1,000 & 0,313 & 0,287 \\
\hline $\begin{array}{l}\text { Jarak Antar Puskesmas } \\
\text { (S8) }\end{array}$ & $\begin{array}{c}\frac{1}{3,040} \\
=0,329\end{array}$ & $\begin{array}{c}\frac{1}{2,840} \\
=0,352\end{array}$ & $\begin{array}{l}\frac{1}{1,840} \\
=0,543\end{array}$ & $\begin{aligned} & \frac{1}{0,323} \\
= & 3,096\end{aligned}$ & $\begin{aligned} & \frac{1}{0,253} \\
= & 3,953\end{aligned}$ & $\begin{aligned} & \frac{1}{0,263} \\
= & 3,802\end{aligned}$ & $\begin{aligned} & \frac{1}{0,313} \\
= & 3,195\end{aligned}$ & 1,000 & 0,480 \\
\hline $\begin{array}{l}\text { Jarak Puskesmas dari } \\
\text { Permukiman (S9) }\end{array}$ & $\begin{aligned} & \frac{1}{1,690} \\
= & 0,592\end{aligned}$ & $\begin{aligned} & \frac{1}{3,240} \\
&= 0,309 \\
&\end{aligned}$ & $\begin{aligned} & \frac{1}{1,640} \\
= & 0,610\end{aligned}$ & $\begin{aligned} & \frac{1}{0,857} \\
= & 1,167\end{aligned}$ & $\begin{aligned} & \frac{1}{0,253} \\
&= 3,953 \\
&\end{aligned}$ & $\begin{aligned} & \frac{1}{1,013} \\
= & 0,987\end{aligned}$ & $\begin{aligned} & \frac{1}{0,287} \\
&= 3,484 \\
&\end{aligned}$ & $\begin{aligned} & \frac{1}{0,480} \\
&= 2,083 \\
&\end{aligned}$ & 1,000 \\
\hline$\sum^{2} K_{-} j$ & 4,480 & 4,102 & 9,785 & 18,805 & 29,782 & 21,918 & 16,692 & 11,955 & 10,460 \\
\hline
\end{tabular}

\subsection{Perhitungan bobot kriteria dan subkriteria}

Pada tahap ini data dari matriks rata-rata perbandingan berpasangan diolah untuk mendapatkan bobot dari masing-masing kriteria dan subkriteria.

\section{a. Perhitungan bobot kriteria}

Menghitung matriks normalisasi rata-rata tiap kolomnya dengan menggunakan persamaan (3) dan (4).

Tabel 7 : Hasil Pembagian Antara Tiap Kriteria dan Penjumlahan Tiap Baris

\begin{tabular}{|l|c|c|c|c|}
\hline \multicolumn{1}{|c|}{ Kriteria $\boldsymbol{j}$} & K1 & K2 & K3 & K4 \\
\hline Kriteria $\boldsymbol{i}$ & 0,212 & 0,451 & 0,158 & 0,371 \\
\hline Kenduduk (K1) & 0,056 & 0,119 & 0,173 & 0,160 \\
\hline Aksesibilitas (K3) & 0,663 & 0,339 & 0,495 & 0,347 \\
\hline Jarak (K4) & 0,070 & 0,091 & 0,174 & 0,122 \\
\hline
\end{tabular}

Tabel 8 : Matriks Normalisasi Kriteria

\begin{tabular}{|l|c|}
\hline \multicolumn{1}{|c|}{ Kriteria } & Hasil Normalisasi \\
\hline Penduduk (K1) & 0,298 \\
\hline Kondisi Geografis (K2) & 0,127 \\
\hline Aksesibilitas (K3) & 0,461 \\
\hline Jarak (K4) & 0,114 \\
\hline
\end{tabular}


Selanjutnya mencari nilai eigen maksimum dengan $n=4$ menggunakan persamaan (5) diperoleh $\lambda_{\text {maks }}=4,247$. Berdasarkan persamaan (6) dan (7) didapat nilai Consistency Index (CI) sebesar 0,082 dan nilai Consistency Ratio (CR) sebesar 0,092. Karena $(C R) \leq 0,1$ perbandingan berpasangan antara kriteria konsisten. Setelah matriks penilaian responden konsisten, maka nilai numerik perbandingan berpasangan tiap kriteria dikonversikan dalam bentuk Triangular Fuzzy Number (TFN) dan dihitung rata-rata geometrik antar kriteria. Dari hasil matriks rata- rata geometrik kemudian dihitung nilai sintesis fuzzynya menggunakan persamaan (9).

Tabel 9 : Rata-Rata Geometrik Antar Kriteria

\begin{tabular}{|l|c|c|c|c|c|}
\hline \multicolumn{1}{|c|}{ Kriteria $\boldsymbol{j}$} & $\begin{array}{c}\text { K1 } \\
\text { Kriteria } \boldsymbol{i}\end{array}$ & $\begin{array}{c}\text { K2 } \\
(\boldsymbol{l}, \boldsymbol{m}, \boldsymbol{u})\end{array}$ & $\begin{array}{c}\text { K3 }, \boldsymbol{u}) \\
(\boldsymbol{l}, \boldsymbol{m}, \boldsymbol{u})\end{array}$ & $\begin{array}{c}\text { K4 } \\
(\boldsymbol{l}, \boldsymbol{m}, \boldsymbol{u})\end{array}$ & $\begin{array}{c}\text { Jumlah Baris } \\
(\boldsymbol{l}, \boldsymbol{m}, \boldsymbol{u})\end{array}$ \\
\hline Penduduk (K1) & 1,$000 ; 1,000 ; 1,000$ & 1,$130 ; 1,652 ; 2,163$ & 0,$454 ; 0,593 ; 0,861$ & 0,$944 ; 1,315 ; 1,719$ & 3,$528 ; 4,560 ; 5,743$ \\
\hline Kondisi Geografis (K2) & 0,$462 ; 0,605 ; 0,885$ & 1,$000 ; 1,000 ; 1,000$ & 0,$483 ; 0,641 ; 0,960$ & 0,$518 ; 0,702 ; 1,096$ & 2,$463 ; 2,948 ; 3,941$ \\
\hline Aksesibilitas (K3) & 1,$161 ; 1,687 ; 2,201$ & 1,$042 ; 1,560 ; 2,069$ & 1,$000 ; 1,000 ; 1,000$ & 1,$011 ; 1,523 ; 2,030$ & 4,$214 ; 5,770 ; 7,300$ \\
\hline Jarak (K4) & 0,$582 ; 0,760 ; 1,059$ & 0,$913 ; 1,424 ; 1,930$ & 0,$493 ; 0,657 ; 0,990$ & 1,$000 ; 1,000 ; 1,000$ & 2,$988 ; 3,841 ; 4,979$ \\
\hline
\end{tabular}

Tabel 10 : Sintesis Matriks Kriteria

\begin{tabular}{|c|c|c|c|}
\hline Sintesis Fuzzy & $\boldsymbol{l}$ & $\boldsymbol{m}$ & $\boldsymbol{u}$ \\
\hline$S_{K 1}$ & 0,161 & 0,266 & 0,435 \\
\hline$S_{K 2}$ & 0,112 & 0,172 & 0,299 \\
\hline$S_{K 3}$ & 0,192 & 0,337 & 0,553 \\
\hline$S_{K 4}$ & 0,136 & 0,224 & 0,377 \\
\hline
\end{tabular}

\section{Keterangan:}

$S_{K 1}=$ Sintesis fuzzy kriteria penduduk

$S_{K 2}=$ Sintesis fuzzy kriteria kondisi geografis

$S_{K 3}=$ Sintesis fuzzy kriteria aksesibilitas

$S_{K 4}=$ Sintesis fuzzy kriteria jarak

Berdasarkan nilai sintesis fuzzy pada Tabel 10, dengan menggunakan persamaan (12) maka diperoleh nilai derajat kemungkinan kriteria sebagai berikut :

$$
\begin{array}{llll}
V\left(S_{K 1} \geq S_{K 2}\right) & =1,000 & V\left(S_{K 3} \geq S_{K 1}\right) & =1,000 \\
V\left(S_{K 1} \geq S_{K 3}\right) & =0,774 & V\left(S_{K 3} \geq S_{K 2}\right) & =1,000 \\
V\left(S_{K 1} \geq S_{K 4}\right) & =1,000 & V\left(S_{K 3} \geq S_{K 4}\right) & =1,000 \\
V\left(S_{K 2} \geq S_{K 1}\right) & =0,595 & V\left(S_{K 4} \geq S_{K 1}\right) & =0,837 \\
V\left(S_{K 2} \geq S_{K 3}\right) & =0,351 & V\left(S_{K 4} \geq S_{K 2}\right) & =1,000 \\
V\left(S_{K 2} \geq S_{K 4}\right) & =0,758 & V\left(S_{K 4} \geq S_{K 3}\right) & =0,621
\end{array}
$$

Berdasarkan persamaan (14) diperoleh bobot nilai dari setiap level kriteria sebagai berikut:

$$
\begin{aligned}
& d^{\prime}\left(A_{1}\right)=\min (1,000 ; 0,774 ; 1,000)=0,774 \\
& d^{\prime}\left(A_{2}\right)=\min (0,595 ; 0,351 ; 0,758)=0,351 \\
& d^{\prime}\left(A_{3}\right)=\min (1,000 ; 1,000 ; 1,000)=1,000 \\
& d^{\prime}\left(A_{4}\right)=\min (0,837 ; 1,000 ; 0,621)=0,621
\end{aligned}
$$

Sehingga nilai bobot vektor dituliskan sesuai dengan persamaan (14) sebagai berikut: 


$$
W^{\prime}{ }_{K}=(0,774 ; 0,351 ; 1,000 ; 0,621)^{T}
$$

Berdasarkan persamaan (16) diperoleh bobot vektor normalisasi dari kriteria sebagai berikut.

$$
W=\left(\frac{0,774}{2,746} ; \frac{0,351}{2,746} ; \frac{1,000}{2,746} ; \frac{0,621}{2,746}\right)=(0,282 ; 0,128 ; 0,364 ; 0,226)
$$

Tabel 11 : Bobot Akhir Kriteria

\begin{tabular}{|l|c|}
\hline \multicolumn{1}{|c|}{ Kriteria } & Bobot akhir \\
\hline Penduduk (K1) & 0,282 \\
\hline Kondisi Geografis (K2) & 0,128 \\
\hline Aksesibilitas (K3) & 0,364 \\
\hline Jarak (K4) & 0,226 \\
\hline
\end{tabular}

Pada Tabel 11 bobot akhir setiap kriteria tidak digunakan dalam perhitungan pemilihan lokasi tetapi bobot tersebut dapat mengingatkan pembaca mengenai hasil atau bobot yang diperoleh dari setiap kriteria.

\section{b. Perhitungan bobot subkriteria}

Menghitung matriks normalisasi dari rata-rata tiap kolomnya dengan menggunakan persamaan (3) dan (4).

Tabel 12 : Hasil Pembagian Antara Tiap Subkriteria dan Penjumlahan Tiap Baris

\begin{tabular}{|l|c|c|c|c|c|c|c|c|c|}
\hline \multicolumn{1}{|c|}{ Subkriteria $\boldsymbol{j}$} & S1 & S2 & S3 & S4 & S5 & S6 & S7 & S8 & S9 \\
Subkriteria $\boldsymbol{i}$ & 0,223 & 0,258 & 0,271 & 0,202 & 0,128 & 0,173 & 0,134 & 0,254 & 0,162 \\
\hline Jumlah Penduduk (S1) & 0,211 & 0,244 & 0,368 & 0,191 & 0,141 & 0,192 & 0,170 & 0,238 & 0,310 \\
\hline Kepadatan Penduduk (S2) & 0,084 & 0,068 & 0,102 & 0,128 & 0,121 & 0,164 & 0,146 & 0,154 & 0,157 \\
\hline Luas Tanah (S3) & 0,059 & 0,068 & 0,043 & 0,053 & 0,107 & 0,137 & 0,019 & 0,027 & 0,082 \\
\hline Kontur Tanah (S4) & 0,059 & 0,058 & 0,028 & 0,017 & 0,034 & 0,014 & 0,021 & 0,021 & 0,024 \\
\hline $\begin{array}{l}\text { Ketersediaan Tempat Parkir } \\
\text { (S5) }\end{array}$ & 0,059 & 0,058 & 0,028 & 0,018 & 0,107 & 0,046 & 0,049 & 0,022 & 0,097 \\
\hline Fasilitas Keamanan (S6) & 0,100 & 0,086 & 0,042 & 0,165 & 0,097 & 0,055 & 0,060 & 0,026 & 0,027 \\
\hline $\begin{array}{l}\text { Ketersediaan Utilitas Publik } \\
\text { (S7) }\end{array}$ & 0,073 & 0,086 & 0,056 & 0,165 & 0,133 & 0,173 & 0,191 & 0,084 & 0,046 \\
\hline Jarak Antar Puskesmas (S8) & 0,132 & 0,075 & 0,062 & 0,062 & 0,133 & 0,045 & 0,209 & 0,174 & 0,096 \\
\hline $\begin{array}{l}\text { Jarak Puskesmas dari } \\
\text { Permukiman (S9) }\end{array}$ & & & & & & & \\
\hline
\end{tabular}

Tabel 13 : Matriks Normalisasi Subkriteria

\begin{tabular}{|l|c|}
\hline \multicolumn{1}{|c|}{ Subkriteria } & Hasil Normalisasi \\
\hline Jumlah Penduduk (S1) & 0,201 \\
\hline Kepadatan Penduduk (S2) & 0,229 \\
\hline Luas Tanah (S3) & 0,125 \\
\hline Kontur Tanah (S4) & 0,066 \\
\hline Ketersediaan Tempat Parkir (S5) & 0,031 \\
\hline Fasilitas Keamanan (S6) & 0,054 \\
\hline Ketersediaan Utilitas Publik (S7) & 0,073 \\
\hline Jarak Antar Puskesmas (S8) & 0,112 \\
\hline Jarak Puskesmas dari Permukiman (S9) & 0,110 \\
\hline
\end{tabular}


Selanjutnya mencari nilai eigen maksimum dengan $n=9$ menggunakan persamaan (5) diperoleh $\lambda_{\text {maks }}=9,981$. Berdasarkan persamaan (6) dan (7) didapat nilai Consistency Index (CI) sebesar 0,123 dan nilai Consistency Ratio (CR) sebesar 0,085. Karena $(C R) \leq 0,1$ perbandingan berpasangan antara subkriteria konsisten. Setelah matriks penilaian responden konsisten, nilai numerik perbandingan berpasangan tiap subkriteria dikonversikan dalam bentuk Triangular Fuzzy Number (TFN) dan dihitung rata-rata geometrik antar subkriteria. Dari hasil matriks rata- rata geometrik kemudian dihitung nilai sintesis fuzzynya menggunakan persamaan (9).

Tabel 14 : Rata-Rata Geometrik Antar Subkriteria

\begin{tabular}{|c|c|c|c|c|c|c|c|c|c|c|}
\hline Subkriteria $i$ & $\begin{array}{c}\text { S1 } \\
(\boldsymbol{l}, \boldsymbol{m}, \boldsymbol{u})\end{array}$ & $\begin{array}{c}\mathbf{S 2} \\
(\boldsymbol{l}, \boldsymbol{m}, \boldsymbol{u})\end{array}$ & $\begin{array}{c}\text { S3 } \\
(\boldsymbol{l}, \boldsymbol{m}, \boldsymbol{u})\end{array}$ & $\begin{array}{c}\text { S4 } \\
(l, m, u)\end{array}$ & $\begin{array}{c}\mathrm{S5} \\
(\boldsymbol{l}, \boldsymbol{m}, \boldsymbol{u})\end{array}$ & $\begin{array}{c}\text { S6 } \\
(l, m, u)\end{array}$ & $\begin{array}{c}\text { S7 } \\
(\boldsymbol{l}, \boldsymbol{m}, \boldsymbol{u})\end{array}$ & $\begin{array}{c}\mathbf{S 8} \\
(\boldsymbol{l}, \boldsymbol{m}, \boldsymbol{u})\end{array}$ & $\begin{array}{c}\text { S9 } \\
(\boldsymbol{l}, \boldsymbol{m}, \boldsymbol{u})\end{array}$ & $\begin{array}{c}\text { Jumlah } \\
\text { Baris } \\
(\boldsymbol{l}, \boldsymbol{m}, \boldsymbol{u})\end{array}$ \\
\hline Jumlah Penduduk (S1) & $\begin{array}{l}1,000 \\
1,000 \\
1,000\end{array}$ & $\begin{array}{c}0,576 \\
0,768 \\
1,009\end{array}$ & $\begin{array}{l}0,859 \\
1,256 \\
1,690\end{array}$ & $\begin{array}{l}1,137 \\
1,657 \\
2,168\end{array}$ & $\begin{array}{l}1,161 \\
1,673 \\
2,180\end{array}$ & $\begin{array}{r}1,161 \\
1,673 \\
2,180\end{array}$ & $\begin{array}{r}0,760 \\
1,143 \\
1,550\end{array}$ & $\begin{array}{r}0,924 \\
1,303 \\
1,709\end{array}$ & $\begin{array}{l}0,668 \\
0,957 \\
1,301\end{array}$ & $\begin{array}{r}8,246 ; \\
11,430 ; \\
14,787\end{array}$ \\
\hline Kepadatan Penduduk (S2) & $\begin{array}{l}0,910 \\
1,303 \\
1,736\end{array}$ & $\begin{array}{l}1,000 \\
1,000 \\
1,000\end{array}$ & $\begin{array}{r}1,096 \\
1,614 \\
2,122\end{array}$ & $\begin{array}{r}1,096 \\
1,614 \\
2,122\end{array}$ & $\begin{array}{l}1,275 \\
1,783 \\
2,287\end{array}$ & $\begin{array}{l}1,275 \\
1,783 \\
2,287\end{array}$ & $\begin{array}{r}0,873 \\
1,256 \\
1,664\end{array}$ & $\begin{array}{l}0,903 \\
1,275 \\
1,679\end{array}$ & $\begin{array}{l}0,979 \\
1,351 \\
1,755\end{array}$ & $\begin{array}{r}9,407 \\
12,979 \\
16,652\end{array}$ \\
\hline Luas Tanah (S3) & $\begin{array}{c}0.592 \\
0,796 \\
1,164\end{array}$ & $\begin{array}{r}0.471 \\
0,620 \\
0,912\end{array}$ & $\begin{array}{l}1.000 \\
1,000 \\
1,000\end{array}$ & $\begin{array}{l}0.748 \\
1,285 \\
1,802\end{array}$ & $\begin{array}{l}1.110 \\
1,623 \\
2,129\end{array}$ & $\begin{array}{r}1,110 \\
1,623 \\
2,129\end{array}$ & $\begin{array}{l}0,805 \\
1,186 \\
1,591\end{array}$ & $\begin{array}{l}0,646 \\
1,046 \\
1,457\end{array}$ & $\begin{array}{l}0,596 \\
1,000 \\
1,413\end{array}$ & $\begin{array}{c}7,078 \\
10,179 \\
13,597\end{array}$ \\
\hline Kontur Tanah (S4) & $\begin{array}{l}0,461 \\
0,603 \\
0,880\end{array}$ & $\begin{array}{l}0,471 \\
0,620 \\
0,912\end{array}$ & $\begin{array}{l}0,555 \\
0,778 \\
1,337\end{array}$ & $\begin{array}{l}1,000 \\
1,000 \\
1,000\end{array}$ & $\begin{array}{l}1,011 \\
1,523 \\
2,030\end{array}$ & $\begin{array}{r}0,923 \\
1,457 \\
1,969\end{array}$ & $\begin{array}{r}0,480 \\
0,633 \\
0,934\end{array}$ & $\begin{array}{l}0,480 \\
0,633 \\
0,934\end{array}$ & $\begin{array}{l}0,551 \\
0,686 \\
1,073\end{array}$ & $\begin{array}{l}5,932 \\
7,933 \\
11,069\end{array}$ \\
\hline $\begin{array}{l}\text { Ketersediaan Tempat } \\
\text { Parkir (S5) }\end{array}$ & $\begin{array}{r}0,459 \\
0,598 \\
0,861\end{array}$ & $\begin{array}{r}0,437 \\
0,561 ; \\
0,784\end{array}$ & $\begin{array}{r}0,470 \\
0,616 \\
0,901\end{array}$ & $\begin{array}{c}0,493 \\
0,656 ; \\
0,989\end{array}$ & $\begin{array}{l}1,000 \\
1,000 \\
1,000\end{array}$ & $\begin{array}{r}0,470 \\
0,616 ; \\
0,901\end{array}$ & $\begin{array}{l}0,493 \\
0,656 ; \\
0,989\end{array}$ & $\begin{array}{l}0,437 \\
0,561 \\
0,784\end{array}$ & $\begin{array}{l}0,437 \\
0,561 ; \\
0,784\end{array}$ & $\begin{array}{l}4,696 \\
5,825 \\
7,993\end{array}$ \\
\hline Fasilitas Keamanan (S6) & $\begin{array}{l}0,459 \\
0,598 \\
0,861\end{array}$ & $\begin{array}{r}0,437 \\
0,561 \\
0,784\end{array}$ & $\begin{array}{r}0,470 \\
0,616 \\
0,901\end{array}$ & $\begin{array}{l}0,508 \\
0,686 \\
1,073\end{array}$ & $\begin{array}{l}1,110 \\
1,623 \\
2,129\end{array}$ & $\begin{array}{l}1,000 \\
1,000 \\
1,000\end{array}$ & $\begin{array}{r}0,536 \\
0,718 \\
1,013\end{array}$ & $\begin{array}{r}0,447 \\
0,576 ; \\
0,813\end{array}$ & $\begin{array}{r}0,549 \\
0,721 \\
1,000\end{array}$ & $\begin{array}{l}5,516 \\
7,099 \\
9,574\end{array}$ \\
\hline $\begin{array}{l}\text { Ketersediaan Utilitas } \\
\text { Publik (S7) }\end{array}$ & $\begin{array}{l}0,645 ; \\
0,875 ; \\
1,316\end{array}$ & $\begin{array}{l}0,601 ; \\
0,796 ; \\
1,146\end{array}$ & $\begin{array}{r}0,628 \\
0,843 \\
1,243\end{array}$ & $\begin{array}{c}0,628 \\
0,843 \\
1,243\end{array}$ & $\begin{array}{r}1,071 \\
1,580 \\
2,085\end{array}$ & $\begin{array}{r}0,987 \\
1,393 \\
1,864\end{array}$ & $\begin{array}{r}1,000 \\
1,000 \\
1,000\end{array}$ & $\begin{array}{l}0,470 \\
0,616 \\
0,901\end{array}$ & $\begin{array}{l}0,449 ; \\
0,582 ; \\
0,830\end{array}$ & $\begin{array}{l}6,479 \\
8,528 ; \\
11,628\end{array}$ \\
\hline $\begin{array}{l}\text { Jarak Antar Puskesmas } \\
\text { (S8) }\end{array}$ & $\begin{array}{r}0,585 \\
0,768 \\
1,082\end{array}$ & $\begin{array}{r}0,596 \\
0,784 \\
1,108\end{array}$ & $\begin{array}{l}0,686 ; \\
0,915 ; \\
1,548\end{array}$ & $\begin{array}{l}0,628 \\
0,843 \\
1,243\end{array}$ & $\begin{array}{l}1,275 \\
1,783 \\
2,287\end{array}$ & $\begin{array}{r}1,230 \\
1,736 \\
2,239\end{array}$ & $\begin{array}{l}1,110 \\
1,623 \\
2,129\end{array}$ & $\begin{array}{l}1,000 \\
1,000 \\
1,000\end{array}$ & $\begin{array}{r}0,482 \\
0,693 \\
1,035\end{array}$ & $\begin{array}{r}7,592 \\
10,145 \\
13,671\end{array}$ \\
\hline $\begin{array}{l}\text { Jarak Puskesmas dari } \\
\text { Permukiman (S9) }\end{array}$ & $\begin{array}{r}0,768 \\
1,045 \\
1,496\end{array}$ & $\begin{array}{c}0,570 \\
0,740 \\
1,021\end{array}$ & $\begin{array}{c}0,833 \\
1,149 ; \\
1,755\end{array}$ & $\begin{array}{l}0,932 ; \\
1,343 ; \\
1,815\end{array}$ & $\begin{array}{r}1,000 \\
1,388 \\
1,821\end{array}$ & $\begin{array}{r}1,000 \\
1,388 \\
1,821\end{array}$ & $\begin{array}{l}1,204 \\
1,719 ; \\
2,226\end{array}$ & $\begin{array}{r}0,967 \\
1,443 ; \\
2,073\end{array}$ & $\begin{array}{r}1,000 \\
1,000 \\
1,000\end{array}$ & $\begin{array}{r}8,274 ; \\
11,215 ; \\
15,028\end{array}$ \\
\hline
\end{tabular}

Tabel 15 : Sintesis Matriks Subkriteria

\begin{tabular}{|c|c|c|c|}
\hline Sintesis Fuzzy & $\boldsymbol{l}$ & $\boldsymbol{m}$ & $\boldsymbol{u}$ \\
\hline$S_{S 1}$ & 0,072 & 0,134 & 0,234 \\
\hline$S_{S 2}$ & 0,083 & 0,152 & 0,263 \\
\hline$S_{S 3}$ & 0,062 & 0,119 & 0,215 \\
\hline$S_{S 4}$ & 0,052 & 0,093 & 0,175 \\
\hline$S_{S 5}$ & 0,041 & 0,068 & 0,126 \\
\hline$S_{S 6}$ & 0,048 & 0,083 & 0,151 \\
\hline$S_{S 7}$ & 0,057 & 0,100 & 0,184 \\
\hline$S_{S 8}$ & 0,067 & 0,119 & 0,216 \\
\hline$S_{S 9}$ & 0,073 & 0,131 & 0,238 \\
\hline
\end{tabular}


Keterangan:

$S_{S 1}=$ Sintesis fuzzy subkriteria jumlah penduduk

$S_{S 2}=$ Sintesis fuzzy subkriteria kepadatan penduduk

$S_{S 3}=$ Sintesis fuzzy subkriteria luas tanah

$S_{S 4}=$ Sintesis fuzzy subkriteria kontur tanah

$S_{S 5}=$ Sintesis fuzzy subkriteria ketersediaan tempat parkir

$S_{S 6}=$ Sintesis fuzzy subkriteria fasilitas keamanan

$S_{S 7}=$ Sintesis fuzzy subkriteria ketersediaan utilitas publik

$S_{S 8}=$ Sintesis fuzzy subkriteria jarak antar puskesmas

$S_{S 9}=$ Sintesis fuzzy subkriteria jarak puskesmas dari permukiman

Berdasarkan nilai sintesis fuzzy pada Tabel 15, dengan menggunakan persamaan (12) diperoleh nilai derajat kemungkinan kriteria sebagai berikut :

\begin{tabular}{|c|c|c|c|c|c|c|c|}
\hline$V\left(S_{S 1} \geq S_{S 2}\right)$ & $=0,893$ & $V\left(S_{S 3} \geq S_{S 4}\right)$ & $=1,000$ & $V\left(S_{S 5} \geq S_{S 6}\right)$ & $=0,839$ & $V\left(S_{S 7} \geq S_{S 8}\right)$ & $=0,860$ \\
\hline$V\left(S_{S 1} \geq S_{S 3}\right)$ & $=1,000$ & $V\left(S_{S 3} \geq S_{S 5}\right)$ & $=1,000$ & $V\left(S_{S 5} \geq S_{S 7}\right)$ & $=0,683$ & $V\left(S_{S 7} \geq S_{S 9}\right)$ & $=0,782$ \\
\hline$V\left(S_{S 1} \geq S_{S 4}\right)$ & $=1,000$ & $V\left(S_{S 3} \geq S_{S 6}\right)$ & $=1,000$ & $V\left(S_{S 5} \geq S_{S 8}\right)$ & $=0,536$ & $V\left(S_{S 8} \geq S_{S 1}\right)$ & 906 \\
\hline$\left(S_{S 1} \geq S_{S 5}\right)$ & 1,000 & $V\left(S_{S 3} \geq S_{S 7}\right)$ & $=1,000$ & $V\left(S_{S 5} \geq S_{S 9}\right)$ & $=0,457$ & $V\left(S_{S 8} \geq S_{S 2}\right)$ &, 801 \\
\hline$V\left(S_{S 1} \geq S_{S 6}\right)$ & 1,000 & $V\left(S_{S 3} \geq S_{S 8}\right)$ & 1,000 & $V\left(S_{S 6} \geq S_{S 1}\right)$ & 0,608 & $V\left(S_{S 8} \geq S_{S 3}\right)$ & 000 \\
\hline$\left(S_{S 1} \geq S_{S 7}\right)$ & 1,000 & $V\left(S_{S 3} \geq S_{S 9}\right)$ & 0,922 & $V\left(S_{S 6} \geq S_{S 2}\right)$ & 0,496 & $V\left(S_{S 8} \geq S_{S 4}\right)$ & 188 \\
\hline$V\left(S_{S 1} \geq S_{S 8}\right)$ & 1,000 & $V\left(S_{S 4} \geq S_{S 1}\right)$ & $=0,715$ & $V\left(S_{S 6} \geq S_{S 3}\right)$ & $=0,712$ & $V\left(S_{S 8} \geq S_{S 5}\right)$ & 000 \\
\hline$V\left(S_{S 1} \geq S_{S 9}\right)$ & 1,000 & $V\left(S_{S 4} \geq S_{S 2}\right)$ & 0,609 & $V\left(S_{S 6} \geq S_{S 4}\right)$ & 0,908 & $V\left(S_{S 8} \geq\right.$ & 000 \\
\hline$V\left(S_{S 2} \geq S_{S 1}\right)$ & 1,000 & $V\left(S_{S 4} \geq S_{S 3}\right)$ & $=0,813$ & $V\left(S_{S 6} \geq S_{S 5}\right)$ & $=1,000$ & $V(S$ & 000 \\
\hline$V\left(S_{S 2} \geq S_{S 3}\right)$ & 1,000 & $V\left(S_{S 4} \geq S_{S 5}\right)$ & 1,000 & $V\left(S_{S 6} \geq S_{S 7}\right)$ & 0,846 & $V\left(S_{S 8} \geq S_{S 9}\right)$ & ,923 \\
\hline$V\left(S_{S 2} \geq S_{S 4}\right)$ & $=1,000$ & $V\left(S_{S 4} \geq S_{S 6}\right)$ & 1,000 & $V\left(S_{S 6} \geq S_{S 8}\right)$ & $=0,700$ & $V\left(S_{S 9} \geq S_{S 1}\right)$ & 982 \\
\hline$V\left(S_{S 2} \geq S_{S 5}\right)$ & 1,000 & $V\left(S_{S 4} \geq S_{S 7}\right)$ & $=0,944$ & $V\left(S_{S 6} \geq S_{S 9}\right)$ & 0,619 & $V\left(S_{S 9} \geq S_{S 2}\right)$ & 881 \\
\hline$V\left(S_{S 2} \geq S_{S 6}\right)$ & $=1,000$ & $V\left(S_{S 4} \geq S_{S 8}\right)$ & $=0,806$ & $V\left(S_{S 7} \geq S_{S 1}\right)$ & $=0,767$ & $V\left(S_{S 9} \geq S_{S 3}\right)$ & 000 \\
\hline$V\left(S_{S 2} \geq S_{S 7}\right)$ & $=1,000$ & $V\left(S_{S 4} \geq S_{S 9}\right)$ & $=0,729$ & $V\left(S_{S 7} \geq S_{S 2}\right)$ & $=0,660$ & $V\left(S_{S 9} \geq S_{S 4}\right)$ & 000 \\
\hline$V\left(S_{S 2} \geq S_{S 8}\right)$ & $=1,000$ & $V\left(S_{S 5} \geq S_{S 1}\right)$ & $=0,450$ & $V\left(S_{S 7} \geq S_{S 3}\right)$ & $=0,865$ & $V\left(S_{S 9} \geq S_{S 5}\right)$ & 000 \\
\hline$V\left(S_{S 2} \geq S_{S 9}\right)$ & $=1,000$ & $V\left(S_{S 5} \geq S_{S 2}\right)$ & $=0,339$ & $V\left(S_{S 7} \geq S_{S 4}\right)$ & $=1,000$ & & 000 \\
\hline$V\left(S_{S 3} \geq S_{S 1}\right)$ & $=0,905$ & $V\left(S_{S 5} \geq S_{S 3}\right)$ & $=0,557$ & $V\left(S_{S 7} \geq S_{S 5}\right)$ & $=1,000$ & $V\left(S_{S}\right.$ & 000 \\
\hline$V\left(S_{S 3} \geq S_{S 2}\right)$ & 0,800 & $V\left(S_{S 5} \geq S_{S 4}\right)$ & $=0,740$ & $V\left(S_{S 7} \geq S_{S 6}\right)$ & $=1,000$ & $V\left(S_{S 9} \geq S_{S 9}\right)$ & 1,000 \\
\hline
\end{tabular}

Berdasarkan persamaan (14) diperoleh bobot nilai setiap level subkriteria sebagai berikut :

$$
\begin{aligned}
& d^{\prime}\left(A_{1}\right)=\min (0,893 ; 1,000 ; 1,000 ; 1,000 ; 1,000 ; 1,000 ; 1,000 ; 1,000)=0,893 \\
& d^{\prime}\left(A_{2}\right)=\min (1,000 ; 1,000 ; 1,000 ; 1,000 ; 1,000 ; 1,000 ; 1,000 ; 1,000)=1,000 \\
& d^{\prime}\left(A_{3}\right)=\min (0,905 ; 0,800 ; 1,000 ; 1,000 ; 1,000 ; 1,000 ; 1,000 ; 0,922)=0,800 \\
& d^{\prime}\left(A_{4}\right)=\min (0,715 ; 0,609 ; 0,813 ; 1,000 ; 1,000 ; 0,944 ; 0,806 ; 0,729)=0,609 \\
& d^{\prime}\left(A_{5}\right)=\min (0,450 ; 0,339 ; 0,557 ; 0,740 ; 0,839 ; 0,683 ; 0,536 ; 0,457)=0,339 \\
& d^{\prime}\left(A_{6}\right)=\min (0,608 ; 0,496 ; 0,712 ; 0,908 ; 1,000 ; 0,846 ; 0,700 ; 0,619)=0,496 \\
& d^{\prime}\left(A_{7}\right)=\min (0,767 ; 0,660 ; 0,865 ; 1,000 ; 1,000 ; 1,000 ; 0,860 ; 0,782)=0,660 \\
& d^{\prime}\left(A_{8}\right)=\min (0,906 ; 0,801 ; 1,000 ; 1,188 ; 1,000 ; 1,000 ; 1,000 ; 0,923)=0,801 \\
& d^{\prime}\left(A_{9}\right)=\min (0,982 ; 0,881 ; 1,000 ; 1,000 ; 1,000 ; 1,000 ; 1,000 ; 1,000)=0,881
\end{aligned}
$$

Sehingga nilai bobot vektor dituliskan sesuai dengan persamaan (15) sebagai berikut: $W_{S}^{\prime}=(0,893 ; 1,000 ; 0,800 ; 0,609 ; 0,339 ; 0,496 ; 0,660 ; 0,801 ; 0,881)^{T}$ 
Berdasarkan persamaan (16) diperoleh bobot vektor normalisasi dari subkriteria sebagai berikut:

$$
\begin{array}{r}
W=\left(\frac{0,893}{6,479} ; \frac{1,000}{6,479} ; \frac{0,800}{6,479} ; \frac{0,609}{6,479} ; \frac{0,339}{6,479} ; \frac{0,496}{6,479} ; \frac{0,660}{6,479} ; \frac{0,801}{6,479} ; \frac{0,881}{6,479}\right) \\
=(0,138 ; 0,154 ; 0,123 ; 0,094 ; 0,052 ; 0,077 ; 0,102 ; 0,124 ; 0,136)
\end{array}
$$

Tabel 16 : Bobot Akhir Subkriteria

\begin{tabular}{|l|c|}
\hline \multicolumn{1}{|c|}{ Subkriteria } & Bobot akhir \\
\hline Jumlah Penduduk (S1) & 0,138 \\
\hline Kepadatan Penduduk (S2) & 0,154 \\
\hline Luas Tanah (S3) & 0,123 \\
\hline Kontur Tanah (S4) & 0,094 \\
\hline Ketersediaan Tempat Parkir (S5) & 0,052 \\
\hline Fasilitas Keamanan (S6) & 0,077 \\
\hline Ketersediaan Utilitas Publik (S7) & 0,102 \\
\hline Jarak Antar Puskesmas (S8) & 0,124 \\
\hline Jarak Puskesmas dari Permukiman (S9) & 0,136 \\
\hline
\end{tabular}

\subsection{Penentuan Alternatif}

Lokasi yang digunakan berada di Kecamatan Buduran, Kecamatan Candi, Kecamatan Tanggulangin dan Kecamatan Gedangan. Empat lokasi tersebut digunakan karena pada setiap kecamatan belum ada puskesmas dengan fasilitas rawat inap. Gambar 4, Gambar 5, Gambar 6 dan Gambar 7 merupakan peta lokasi di empat kecamatan yang dipilih, sehingga membantu dalam pencarian lokasi. Berikut alternatif dalam pemilihan lokasi puskesmas baru:

Tabel 17 : Alternatif Lokasi

\begin{tabular}{|l|l|l|}
\hline No & Kecamatan & \multicolumn{1}{c|}{ Lokasi } \\
\hline 1. & Buduran & $\begin{array}{l}\text { Jl. Siwalanpanji II, Bedrek, Siwalanpanji, Kec. Buduran, } \\
\text { Kab.Sidoarjo }\end{array}$ \\
\hline 2. & Candi & $\begin{array}{l}\text { Jl. Ngampelsari, Kedinding, Ngampelsari, Kec.Candi, Kab. } \\
\text { Sidoarjo }\end{array}$ \\
\hline 3. & Tanggulangin & $\begin{array}{l}\text { Jl. Manunggal Amd, Kedunggiling, Gelang, } \\
\text { Kec.Tanggulangin, Kab. Sidoarjo }\end{array}$ \\
\hline 4. & Gedangan & $\begin{array}{l}\text { Jl. Raya Sedati No.36, Ketajen, Kec.Gedangan, } \\
\text { Kab.Sidoarjo }\end{array}$ \\
\hline
\end{tabular}

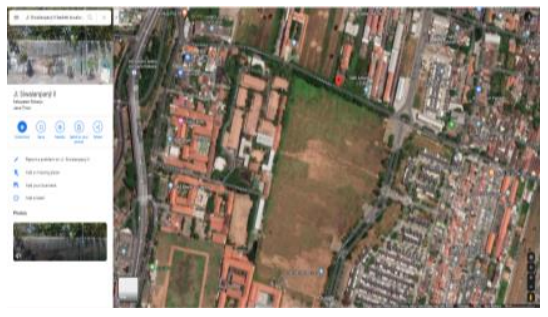

Gambar 1 : Peta Lokasi di Kecamatan Buduran 


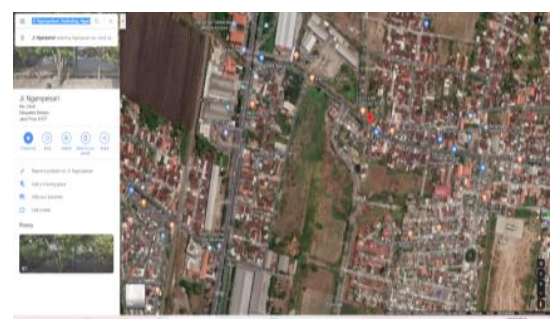

Gambar 2 : Peta Lokasi di Kecamatan Candi

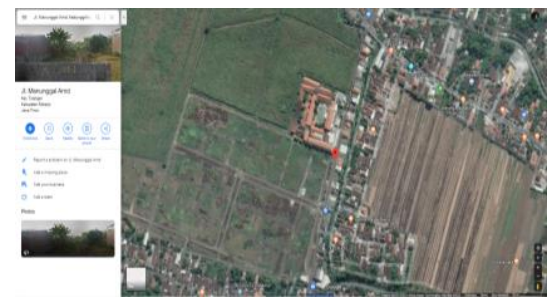

Gambar 3 : Peta Lokasi di Kecamatan Tanggulangin

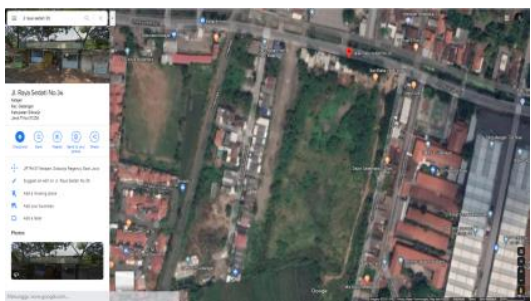

Gambar 4 : Peta Lokasi di Kecamatan Gedangan

\subsection{Perhitungan bobot alternatif}

Setelah diperoleh bobot masing-masing kriteria dan subkriteria selanjutnya dilakukan perhitungan bobot tiap altenatif. Dimana data dalam pemilihan lokasi dinormalisasi terlebih dahulu dalam range yang sama yaitu $[0,1]$ supaya data terdistribusi secara merata tanpa mengurangi bobot nilai sebenarnya dengan menggunakan persamaan berikut.

$$
y=\frac{x-\text { min value }}{\text { max value-min value }}
$$

dengan:

$x=$ nilai sebelum normalisasi

$y=$ nilai sesudah normalisasi

min value $=$ nilai minimum dari seluruh nilai

max value $=$ nilai maksimum dari seluruh nilai 
Tabel 18 : Data Jumlah Penduduk

\begin{tabular}{|l|l|c|c|}
\hline No & Kecamatan & Jumlah penduduk (orang) & Normalisasi \\
\hline 1. & Buduran & 108.457 & 0,029 \\
\hline 2. & Candi & 168.779 & 1,000 \\
\hline 3. & Tanggulangin & 106.685 & 0 \\
\hline 4. & Gedangan & 134.787 & 0,453 \\
\hline
\end{tabular}

Sumber: BPS dalam angka 2019

Tabel 19 : Data Kepadatan Penduduk

\begin{tabular}{|l|l|c|c|}
\hline No & Kecamatan & Kepadatan penduduk $\left(\mathbf{k m}^{\mathbf{2}}\right)$ & Normalisasi \\
\hline 1. & Buduran & $2.589,32$ & 0 \\
\hline 2. & Candi & $4.070,62$ & 0,500 \\
\hline 3. & Tanggulangin & $3.282,84$ & 0,234 \\
\hline 4. & Gedangan & $5.549,54$ & 1,000 \\
\hline
\end{tabular}

Sumber: BPS dalam angka 2019

Tabel 20 : Data Luas Tanah Lokasi

\begin{tabular}{|l|l|c|c|}
\hline No & Kecamatan & Luas tanah $\left(\mathbf{m}^{\mathbf{2}}\right)$ & Normalisasi \\
\hline 1. & Buduran & 64,061 & 0,689 \\
\hline 2. & Candi & 47,069 & 0,443 \\
\hline 3. & Tanggulangin & 85,551 & 1,000 \\
\hline 4. & Gedangan & 16,474 & 0 \\
\hline
\end{tabular}

Sumber: Google Earth Pro

Tabel 21 : Data Kontur Tanah Lokasi

\begin{tabular}{|l|l|c|c|}
\hline No & \multicolumn{1}{|c|}{ Kecamatan } & Kontur tanah (ft) & Normalisasi \\
\hline 1. & Buduran & 21,5 & 0,113 \\
\hline 2. & Candi & 41,9 & 1,000 \\
\hline 3. & Tanggulangin & 18,9 & 0 \\
\hline 4. & Gedangan & 22,8 & 0,170 \\
\hline
\end{tabular}

Sumber: Google Earth Pro

Tabel 22 : Data Jarak Lokasi ke Polsek Terdekat

\begin{tabular}{|l|l|c|c|}
\hline No & Kecamatan & Jarak lokasi ke polsek terdekat $(\mathbf{k m})$ & Normalisasi \\
\hline 1. & Buduran & 2,8 & 0,160 \\
\hline 2. & Candi & 3,3 & 0,259 \\
\hline 3. & Tanggulangin & 7,3 & 1,000 \\
\hline 4. & Gedangan & 1,9 & 0 \\
\hline
\end{tabular}

Sumber: Google Maps 
Tabel 23 : Data Krisis Air Bersih

\begin{tabular}{|l|l|c|c|}
\hline No & Kecamatan & Krisis air bersih & Normalisasi \\
\hline 1. & Buduran & Tidak ada & 1,000 \\
\hline 2. & Candi & Tidak ada & 1,000 \\
\hline 3. & Tanggulangin & Ada & 0 \\
\hline 4. & Gedangan & Tidak ada & 1,000 \\
\hline
\end{tabular}

Tabel 24 : Data Jarak Lokasi ke Puskesmas Terdekat

\begin{tabular}{|l|l|c|c|}
\hline No & Kecamatan & Jarak lokasi ke puskesmas terdekat $(\mathbf{k m})$ & normalisasi \\
\hline 1. & Buduran & 2,7 & 0,098 \\
\hline 2. & Candi & 2,3 & 0,049 \\
\hline 3. & Tanggulangin & 10,1 & 1,000 \\
\hline 4. & Gedangan & 1,9 & 0 \\
\hline
\end{tabular}

Sumber: Google Maps

Tabel 25 : Data Jarak Lokasi ke Permukiman

\begin{tabular}{|l|l|c|c|}
\hline No & Kecamatan & Jarak lokasi ke permukiman $(\mathbf{k m})$ & normalisasi \\
\hline 1. & Buduran & 0,30 & 0,250 \\
\hline 2. & Candi & 0,45 & 1,000 \\
\hline 3. & Tanggulangin & 0,35 & 0,500 \\
\hline 4. & Gedangan & 0,25 & 0 \\
\hline
\end{tabular}

Sumber: Google Maps

Pada penelitian ini data luas tanah lokasi juga digunakan sebagai data ketersediaan tempat parkir karena diasumsikan luas tempat parkir sama seperti luas tanah lokasi, setelah semua data diperoleh selanjutnya data diolah menggunakan bobot hasil FANP, yaitu:

(Data jumlah penduduk hasil normalisasi $\times 0,138)+$

(Data kepadatan penduduk hasil normalisasi $\times 0,154)+$

(Data luas tanah hasil normalisasi $\times 0,123)+$

(Data kontur tanah hasil normalisasi $\times 0,094)+$

(Data ketersediaan tempat parkir hasil normalisasi $\times 0,052)+$

(Data fasilitas keamanan hasil normalisasi $\times 0,077)+$

(Data ketersediaan utilitas publik hasil normalisasi $\times 0,102)+$

(Data jarak lokasi ke puskesmas terdekat hasil normalisasi $\times 0,124)+$

(Data jarak lokasi ke pemukiman hasil normalisasi $\times 0,136)$. Diperoleh bobot setiap alternatif sebagai berikut.

Tabel 26 : Bobot Alternatif Lokasi

\begin{tabular}{|l|c|l|c|c|}
\hline No & Kecamatan & \multicolumn{1}{|c|}{ Lokasi } & Bobot & Peringkat \\
\hline 1. & Buduran & $\begin{array}{l}\text { Jl. Siwalanpanji II, Bedrek, Siwalanpanji, Kec. } \\
\text { Buduran, Kab.Sidoarjo }\end{array}$ & 0,296 & $\mathbf{4}$ \\
\hline 2. & Candi & Jl. Ngampelsari, Kedinding, Ngampelsari, & 0,651 & $\mathbf{1}$ \\
\hline
\end{tabular}




\begin{tabular}{|l|c|l|c|c|}
\hline & & Kec.Candi, Kab. Sidoarjo & & \\
\hline 3. & $\begin{array}{c}\text { Tanggulang } \\
\text { in }\end{array}$ & $\begin{array}{l}\text { Jl. Manunggal Amd, Kedunggiling, Gelang, } \\
\text { Kec.Tanggulangin, Kab. Sidoarjo }\end{array}$ & 0,480 & $\mathbf{2}$ \\
\hline 4. & Gedangan & $\begin{array}{l}\text { Jl. Raya Sedati No.36, Ketajen, Kec.Gedangan }, \\
\text { Kab.Sidoarjo }\end{array}$ & 0,334 & $\mathbf{3}$ \\
\hline
\end{tabular}

\section{Kesimpulan}

Berdasarkan hasil analisis dan perhitungan yang telah dilakukan diperoleh kesimpulan bahwa pemilihan lokasi puskesmas baru di Kabupaten Sidoarjo dapat dilakukan dengan menggunakan metode Fuzzy Analytical Network Process (FANP) untuk menentukan bobot masing-masing kriteria dan sub kriteria. Adapun kriteria dan subkriteria yang digunakan adalah Penduduk (Jumlah Penduduk, Kepadatan Penduduk), Kondisi Geografis (Luas Tanah, Kontur Tanah), Aksesibilitas (Ketersediaan Tempat Parkir, Fasilitas Keamanan, Ketersediaan Utilitas Publik), dan Jarak (Jarak Antar Puskesmas, Jarak Puskesmas dari Permukiman). Sedangkan alternatif lokasi yang digunakan terdiri atas empat kecamatan yang belum mempunyai puskesmas dengan fasilitas rawat inap, yaitu Kecamatan Buduran, Kecamatan Candi, Kecamatan Tanggulangin, dan Kecamatan Gedangan. Diperoleh hasil perhitungan dalam pemilihan lokasi terbaik puskesmas baru menunjukkan bahwa bobot lokasi di Kecamatan Buduran sebesar 0,296, bobot lokasi di Kecamatan Candi sebesar 0,651, bobot lokasi di Kecamatan Tanggulangin sebesar 0,480, dan bobot lokasi di Kecamatan Gedangan sebesar 0,334. Lokasi di Kecamatan Candi terpilih sebagai lokasi terbaik karena memiliki bobot tertinggi yang berada di Jl. Ngampelsari, Kedinding, Ngampelsari, Kec.Candi, Kab. Sidoarjo.

\section{Daftar Pustaka}

[1] Permenkes, "PERATURAN MENTERI KESEHATAN REPUBLIK INDONESIA NOMOR 75 TAHUN 2014,” vol. 2014, no. June, pp. 1-2, 2014.

[2] Dinkes Sidoarjo, Profil Kesehatan Kabupaten Sidoarjo Tahun 2017. 2017.

[3] Dinkes Sidoarjo, Profil Kesehatan Kabupaten Sidoarjo Tahun 2018. 2018.

[4] Badan Pusat Statistik Kabupaten Sidoarjo, Desa dan Kelurahan per Kecamatan Tahun 2014. Kabupaten Sidoarjo, 2019.

[5] S. Kusumadewi, S. Hartati, A. Harjoko, and R. Wardoyo, Fuzzy Multi-Attribute Decision Making (FUZZY MADM). Graha Ilmu, 2006.

[6] L. Mikhailov and M. G. Singh, "Fuzzy analytic network process and its application to the development of decision support systems," IEEE Trans. Syst. Man Cybern. Part C Appl. Rev., vol. 33, no. 1, pp. 33-41, 2003.

[7] G. N. Savira and Y. P. Astuti, "Penerapan Metode Fuzzy Analytic Network Process (Fanp) Pada Penentuan Penerima Beasiswa Peningkatan Prestasi Akademik (Ppa) Di Fmipa Unesa," Math Unesa, vol. 7, no. 3, 2019.

[8] H. Shahbandarzazeh and A. Ghorbanpoour, "The Applying ISM/FANP Approach for Appropriate Location Selection of Health Centers," vol. 4, pp. 5-28, 2011.

[9] M. Oktavia and I. G. N. R. Usadha, "Penerapan Fuzzy Analytical Network Process Dalam Menentukan Prioritas Pemeliharaan Jalan," Jur. Mat. Fak. Mat. dan Ilmu Pengetah. Alam, Inst. Teknol. Sepuluh Nop., vol. 1, no. 1, pp. 1-6, 2013.

[10] S. Kusumadewi and H. Purnomo, Aplikasi Logika Fuzzy untuk Pendukung Keputusan. Graha Ilmu, 2004. 
[11] J. Y. Wei and C. H. Wang, "A novel approach-fuzzy anp for distribution center location," Proc. 2009 Int. Conf. Mach. Learn. Cybern., vol. 1, no. July, pp. 537-542, 2009.

[12] A. Febriyanti, A. Lutfi NA, and H. Sharafina, "Penerapan Analytical Network Process Dalam Pemilihan Lokasi Cabang Arosah Fashion,” no. 2006, pp. 256-263, 2019.

[13] R. Saaty, Fundamentals of the Analytic Network Process. Pittsburgh: ISAHP Kobe, 1999.

[14] J. L. Da Silveira Guimarães and V. A. P. Salomon, "ANP applied to the evaluation of performance indicators of reverse logistics in footwear industry," Procedia Comput. Sci., vol. 55, no. Itqm, pp. 139-148, 2015.

[15] R. Ardiansyah, M. A. Muslim, and R. N. Hasanah, "Analisis Metode Fuzzy Analytical Network Process untuk Sistem Pengambilan Keputusan Pemeliharaan Jalan," J. Nas. Tek. Elektro dan Teknol. Inf., vol. 5, no. 2, pp. 122-128, 2016.

[16] D. Puspitasari, "Penerapan Metode Fuzzy Analytical Hierarchy Process Dalam Pennetuan Kriteria Penilian Performa Vendor," 2009.

[17] R. Saaty, The Analytic Hierarchy Process - What It Is and How It Is Used. 1987.

[18] T. . Saaty and L. . Vargas, Models, Methods, Concepts and Applications of the Analytic Hierarchy Process (2nd ed). New York: Springer, 2012.

[19] K. J. Wang, Y. D. Lestari, and V. N. B. Tran, "Location Selection of High-tech Manufacturing Firms by a Fuzzy Analytic Network Process: A Case Study of Taiwan High-tech Industry," Int. J. Fuzzy Syst., vol. 19, no. 5, pp. 1560-1584, 2017.

[20] N. Erginel and S. Senturk, "Ranking of the GSM operators with fuzzy ANP," Proc. World Congr. Eng. 2011, WCE 2011, vol. 2, no. July 2011, pp. 1116-1121, 2011.

[21] D. . Chang, Applications of the Extent Analysis Method on Fuzzy AHP. European Journal of Operational Research, 1996. 